\title{
Postural hypotension associated with inappropriate choice of drug treatment of benign prostatic hyperplasia
}

\author{
Camilo Domínguez-Domínguez ${ }^{1}$, Carlos Calderón-Ospina ${ }^{2}$ \\ Escuela de Medicina y Ciencias de la Salud. Universidad del Rosario. Carrera 24 No 63C-69. \\ Bogotá, D. C., Colombia. \\ ${ }^{1}$ Correo electrónico: camilo.dominguez@urosario.edu.co. \\ ${ }^{2}$ Correo electrónico: carlos.calderon@urosario.edu.co. \\ Recibido para evaluación: 25 de abril de 2015. \\ Aceptado para publicación: 8 de septiembre de 2015.
}

\section{SUMMARY}

A case of a 76 year old Colombian patient who developed an episode of postural hypotension, after using $4 \mathrm{mg}$ of doxazosin for treatment of benign prostatic hypertrophy $(\mathrm{BPH})$ is presented. Because of his age and severity of symptoms (asthenia, weakness, adynamia), the patient was hospitalized. Changing doxazosin by tamsulosin allowed control of symptoms of $\mathrm{BPH}$ with no further episodes of orthostatic hypotension.

Key words: Prostatic hyperplasia, orthostatic hypotension, adrenergic alpha-1 receptor antagonists, doxazosin, tamsulosin.

\section{RESUMEN}

\section{Hipotensión postural asociada con una escogencia inadecuada del tratamiento medicamentoso de la hiperplasia prostática benigna}

Se presenta el caso de un paciente colombiano de 76 años quien sufrió un episodio de hipotensión postural, después de tomar doxazosina de $4 \mathrm{mg}$ para el manejo de la hiperplasia prostática benigna (HPB). Debido a la severidad de los síntomas (astenia, debilidad y adinamia), el paciente fue hospitalizado. El cambio de doxazosina por tamsulosina permitió el control de los síntomas de la $\mathrm{HPB}$ sin episodios ulteriores de hipotensión ortostática. 
Palabras clave: hiperplasia prostática, hipotensión ortostática, antagonistas adrenérgicos alfa, doxazosina, tamsulosina.

\section{BACKGROUND}

Benign prostatic hypertrophy $(\mathrm{BPH})$ is a relatively common problem in elderly men. Although the pharmacological management of this condition is based on the use of alpha 1-adrenergic antagonists and inhibitors of 5 alpha reductase, the appropriate choice of drug treatment is essential to avoid complications of which the most important one is postural hypotension, as it was the case with our patient, who presented postural hypotension with marked symptoms due to the use of an non - selective alpha receptor antagonist (doxazosin). This case illustrates the importance of optimal selection of drug treatment, dose adjustment and monitoring of adverse drug effects to prevent potentially serious adverse events.

\section{CASE PRESENTATION}

A 76-year-old Hispanic man presented with rapid onset asthenia, adynamia and weakness at shifting from being lying down to standing up. The patient refers these symptoms from the day before he started to take doxazosin orally 4 milligrams a day. His medical history includes chronic gastritis and benign prostatic hypertrophy recently diagnosed. Examination on admission revealed a temperature of $37^{\circ} \mathrm{C}$, heart rate of 60 beats per min, blood pressure of 104/68 mm Hg lying down; and 82/58 $\mathrm{mm} \mathrm{Hg}$ standing up, respiratory rate of 16 breaths per min and oxygen saturation of $91 \%$ with pulse oximetry without supplementary oxygen. Conscious, alert, orientated, hydrated. Digital rectal exam revealed a prostate Grade III, soft and smooth consistency. Clinical examination was unremarkable. The value of serum PSA was $2.5 \mathrm{ng} / \mathrm{mL}$. The values of urinalysis, creatinine, BUN and blood count were within normal limits. Therefore a diagnosis of orthostatic hypotension was made as an adverse drug reaction to doxazosin. The patient was hospitalized. He was checked up by the urology service that stopped doxazosin and started tamsulosin. The patient was checked up a month later, without new orthostatic hypotension episodes.

\section{Discussion}

Treatment of benign prostatic hyperplasia (BPH) can be medical or surgical [1]. The pharmacological treatment options include alpha- adrenergic antagonists, 5-alpha 
reductase inhibitors and some dietary supplements and natural products such as betasitosterol, Pygeumafricanum and grass pollen extract Secalecereale sold in some countries as Cernilton ${ }^{\circledR}[1-3]$.

Regarding alpha adrenergic antagonists or alpha blockers, these reduce smooth muscle tone of the bladder neck, thereby improving the flow of urine. It is recommended that they be used in patients with moderate to severe urinary symptoms related to an International Prostate Symptom Score (I- PSS) of 8 or more, as it was the case in this patient.

In turn, there are three types of receptors called alpha- 1 adrenergic $1 \mathrm{a}, 1 \mathrm{~b}$ and $1 \mathrm{c}$, the first one being predominant in the prostate, bladder neck and urethra. There are two specific drugs for alpha 1a receptors: tamsulosin and silodosin, having much lower affinity for alpha $1 \mathrm{~b}$ and alpha $1 \mathrm{c}$ receptors, responsible for maintaining vascular tone induced by adrenergic ligands [1]. Non-selective receptor alpha blockers include doxazosin, terazosin, prazosin, alfuzosin and indoramin. Because they are non-selective molecules, they generate significant vasodilation; therefore they are preferred in the treatment of benign prostatic hyperplasia accompanied by hypertension, or even they are indicated as monotherapy in the treatment of hypertension as second line drugs $[1,2]$.

However, its use in non-hypertensive patients like this, with $\mathrm{PBH}$ as only condition, can lead to severe postural hypotension as an adverse reaction to the drug, putting them on an increased risk of dizziness, syncope and falls, another morbidity and even mortality [4].

Precisely, in order to determine the potential of vasodilatation caused by tamsulosin and subsequent hypotension compared to alpha 1 adrenergic not selective antagonists, a comparative study was carried out in 10 healthy volunteers previously treated with phenylephrine, a potent vasoconstrictor that acts as an alpha 1 receptors agonist. The results were conclusive to prove that terazosin reversed the vasoconstriction induced by phenylephrine, while tamsulosin virtually lacked of the effects on physiological parameters indicative of this phenomenon (blood flow and arterial pressure values) [5].

In fact, three alpha 1-adrenergic non-selective antagonists (doxazosin, prazosin, terazosin) have the black box warning issued by the FDA of severe hypotension and syncope, especially after the first dose, as was the case in our patient [6].

However, it is noteworthy that the use of tamsulosin also carries a risk of generating low blood pressure, although this is lower than that generated by non-selective alphaadrenergic antagonists. In this way a cohort study conducted in US patients, it was found that the incidence of severe hypotension (requiring hospital admission) with tamsulosin was extremely low (42.4 events per 10,000 person years) [6]. Also it was estimated that the risk of severe hypotension is higher in the first 8 weeks of treatment [6]. 
This is also the case for silodosin. The manufacturer establish that it can produce orthostatic hypotension, dizziness, or syncope [7]. Silodosin has a few drug interactions, for example with metabolic inducers and inhibitors like calcium channel antagonists, macrolides and antifugal agents (e.g., ketoconazole) because it is a substrate of Uridine Diphosphate-glucuronosyltransferase (UGT) 2B7 [7].

In this vein, a systematic review that included 26 randomized trials of alpha- 1 adrenergic antagonists for the treatment of BPH found that vascular adverse events defined as dizziness, syncope or hypotension had the following comparative OR: 3.71 (95\% CI 2.48 - 5.53) with terazosin, 3.32 (95\% CI 2.1 - 5.23) with doxazosin, 1.66 (95\% CI 1.17 - 2.36) with alfuzosin and 1.42 (95\% CI 0.99 - 2.05) with tamsulosin (8). Thus, there is first level evidence regarding tamsulosin is safer than non - selective alpha-1 receptor antagonists, as regards the possibility of generating vascular adverse events [8].

In conclusion, it is considered that two medication errors could happened in this patient; the first regarding with the selection of the drug for BPH treatment, and secondly for not taken care to warn the patient about a possible first-dose hypotension, which in fact occurred, and was severe enough to warrant admission to the hospital.

\section{Causality assessment}

Regarding causality assessment we used the Naranjo algorithm [9] and World Health Organization - Uppsala Monitoring Centre (WHO-UMC) scale [10], with the following results:

Naranjo's Algorithm:

1. Are there previous conclusive reports on this reaction?

Yes +1

2. Did adverse event appear after the suspected drug was given?

Yes +2

3. Did the adverse reaction improve when the drug was discontinued or a specific antagonist was given?

Yes 0

4. Did the adverse reaction appear when the drug was readministered?

Not known or not done 0

5. Are there alternative causes that could have caused the reaction?

$\mathrm{No}+2$ 
6. Did the reaction reappear when a placebo was given? Not known or not done 0

7. Was the drug detected in any body fluid in toxic concentrations?

Not known or not done 0

8. Was the reaction more severe when the dose was increased, or less severe when the dose was decreased?

Not known or not done 0

9. Did the patient have a similar reaction to the same or similar drugs in any previous exposure?

Not known or not done 0

10. Was the adverse event confirmed by any objective evidence?

Yes +1

\section{Score: 6, Probable adverse drug reaction}

WHO-UMC: Probable/Likely Event or laboratory test abnormality, with reasonable time relationship to drug intake. Unlikely to be attributed to disease or other drugs. Response to withdrawal clinically reasonable. Rechallenge not required.

The case was reported to the Pharmacovigilance Committee of the institution, and reported to the National Pharmacovigilance Program at INVIMA.

\section{LEARNING POINTS}

- To consider tamsulosin or silodosin before than a non-specific $\alpha 1$-adrenergic blocking agent, in the initial pharmacological management of benign prostatic hypertrophy.

- Start doxazosin, $1 \mathrm{mg} /$ daily in eligible patients for the drug.

- To recognize the postural hypotension as a frequent adverse effect from $\alpha 1$-adrenergic blocking agents, especially in elderly patients.

- To warn patients about this adverse reaction and to explain them the alarm signs of this condition.

\section{REFERENCES}

1. T.J. Wilt, J. N'Dow. Benign prostatic hyperplasia. Part 2 - management, BMJ, 336, 7637 (2008). 
2. M. Oelke, A. Bachmann, A. Descazeaud, M. Emberton, S. Gravas, M.C. Michel, J. N’Dow, I. Nordling, J.J. de la Rosette, European Association of Urology. EAU guidelines on the treatment and follow-up of non-neurogenic male lower urinary tract symptoms including benign prostatic obstruction, Eur. Urol., 64, 2 (2013).

3. T.H. Kim, H.J. Lim, M.S. Kim, M.S. Lee, Dietary supplements for benign prostatic hyperplasia: An overview of systematic reviews, Maturitas, 73, 3 (2012).

4. S.R. Fine, P. Ginsberg, Alpha-adrenergic receptor antagonists in older patients with benign prostatic hyperplasia: Issues and potential complications, J. Am. Osteopath. Assoc., 108, 7 (2008).

5. K. Harada, M. Ohmori, A. Fujimura, Comparison of the antagonistic activity of tamsulosin and doxazosin at vascular alpha1-adrenergic receptors in humans, Naunyn-Schmiedeberg's Arch. Pharmacol., 354, 5 (1996).

6. S.T. Bird, J.A. Delaney, J.M. Brophy, M. Etminan, S.C. Skeldon, A.G. Hartzema, Tamsulosin treatment for benign prostatic hyperplasia and risk of severe hypotension in men aged 40-85 years in the United States: Risk window analyses using between and within patient methodology, BMJ, 347 (2013).

7. Watson Pharma. Rapaflo (silodosin) capsules prescribing information. Corona, CA, 2008, Oct.

8. J.C. Nickel, S. Sander, T.D. Moon, A meta-analysis of the vascular-related safety profile and efficacy of alpha-adrenergic blockers for symptoms related to benign prostatic hyperplasia, Int. J. Clin. Pract., 62, 10 (2008).

9. C.A. Naranjo, U. Busto, E.M. Sellars, P. Sandor, I. Ruiz, E.A. Roberts et al., A method for estimating the probability of adverse drug reactions, Clin. Pharmacol. Ther., 30, 239 (1981).

10. The World Health Organization - Uppsala Monitoring Centre. The use of the WHO-UMC system or standardised case causality assessment. Available from: http://who-umc.org/Graphics/24734.pdf. Last access: September $4^{\text {th }} 2015$. 